\title{
AN ACCOUNT OF GREGORY BAR HEBRAEUS ABU AL-FARAJ AND HIS RELATIONS WITH THE MONGOLS OF PERSIA
}

\author{
GEORGE LANE \\ SCHOOL OF ORIENTAL AND AFRICAN STUDIES \\ LONDON, UNITED KINGDOM
}

\section{INVADERS FROM THE EAST}

[1] Writing not long after the reign of the Saljuq Sultan Malik-Shah, the Armenian chronicler Matthew of Edessa, who was certainly no champion of Islam, was to write, "The reign of Malik-Shah was favoured by God; his rule extended to all lands and he brought peace to Armenia."1 After his death he eulogised over the Turkish Sultan, "In this same year (1092 CE) died the great Sultan MalikShah the Conqueror who was father and parent to all (his subjects) and a benevolent, merciful, and kind man towards all (people)."2 Though arguably more sympathetic to the Christians than to others among their subjects, the early Il-Khan rulers, especially the founder of the dynasty, Hulegu Khan, were similarly eulogised by their contemporary Christian historians and, as in the case of Matthew writing of his Saljuq king, this praise would appear to have been, in part at least, quite sincere. Bar Hebraeus mourned his King of Kings' passing with these words:

1 Armenia and the Crusades. The Chronicle of Matthew of Edessa. Tr. A.E. Dostourian (New York: University Press of America, 1993) 137.

2 Ibid., 153. 
The wisdom of this man, and his greatness of soul, and his wonderful actions are incomparable. And in the days of summer Tokuz Khatun, the believing queen, departed, and great sorrow came to all Christians throughout the world because of the departure of these two great lights, who made the Christian religion triumphant. ${ }^{3}$

The connection between these two great rulers, the Saljuq MalikShah and the founder of the Il-Khanid dynasty, Hulegu Khan, was that both were from the lands of Turan or beyond and both were all powerful and had been successful in subduing to a relative extent the anarchy that was so often the norm in northern Mesopotamia with its patchwork of atabegates and sultanates playing their tireless game of musical thrones.

Bar Hebraeus (1226-86) did not shrink from cataloguing and describing the horrors endured by all sections of the population of eastern Anatolia, Kurdistan and the march lands of Syria at the hands of the Mongol invaders. Yet he was ultimately able to place such atrocities into context and to perceive a reward for those years of hardship in the guise of the comparative equity evident in the reign of the early Mongol Il-Khans and their eastern overlords.

The kingdom remained the peculiar possession of Kublai Khan, the just and wise king, and lover (or, friend) of the Christians; and he honoured the men of books, and the learned men, and the physicians of all nations. ${ }^{4}$

This was in sharp contrast to other historians of his time who were quick to lay the blame for the people's calamities on their past sins and on a vengeful God. Vardan was one such who wrote,

All were given into their [Mongols'] hands in a short time, without labor or effort, so that we might know that it is the hand of the Lord that has given our land as provider for foreigners before our own eyes. ${ }^{5}$

${ }^{3}$ Bar Hebraeus, The Chronography of Abu'l-Faraj Bar Hebraeus, tr. Ernest Wallis Budge (Oxford, 1932) 444.

${ }^{4}$ Ibid., 439.

5 Vardan, The Historical Compilation of Vardan Arewelci, tr. R.W. Thomson, Dumbarton Oaks Papers 43 (1989): 125-226, chapter 85. 
and Grigor of Akanc" was another claiming that "the Lord roused them [the Mongols] in his anger as a lesson to us, because we had not kept his commandments." 6 Bar Hebraeus rarely passed judgement on the Mongols' raids and often explained their deeds as just rewards for the victim's personal behaviour.

And from there the King of Kings [Hulegu] went against Harim, and he asked [the citizens] to surrender, and [said that] he would swear to them that he would not harm them. And the fools replied, "Though thou art king thy religion is not known. By what are we to make thee swear? But if Fakhr ad-Din, the governor of the fortress of Aleppo, will swear to us that he will not harm us, we will come down." And the King of Kings commanded Fakhr ad-Din, who went down and swore to them. And they opened the gates of the fortress and came down. And the King of Kings commanded, and they were all killed, men and women, and sons, and daughters, also sucking children; ${ }^{7}$

The inability of any group or state to sustain effective opposition to the Mongols added to the belief by most, enemies and allies alike, that the Mongols' ascendancy was inevitable but that in their harsh rule and unassailable power God's clemency must somehow be secretly manifest. "The throne of God is established through righteous judgement." "So concluded the Armenian cleric Vardan in his address to "the powerful, valiant, and victorious Hulawu." However, the Muslim Juwayni saw his masters' destruction of a detested rival, the Isma'ili Imam of Alamut, follower of a "false" Prophet of Islam as proof of the ultimate justice of God's mysterious ways. "the truth of God's secret intent by the rise of Chingiz Khan has become clear." 10

${ }^{6}$ Grigor of Akanc' History of the Nation of Archers, tr. R. P. Blake \& R. Frye (Harvard University Press, 1954) 291.

${ }^{7}$ Bar Hebraeus, The Chronography, 436.

8 Vardan, The Dumbarton Oaks Papers 43, 1989. Harvard University. p. 96 (157).

${ }^{9}$ Vardan, The Historical Compilation, 97.

${ }^{10}$ J.A. Boyle (tr. \& ed.), Ata Malik Juvaini, Genghis Khan: The History of the World-Conqueror (Manchester University Press, 1997) 638; 'Ala al-Din Ata Malik Juwayni (ed.), Mirza Mohammed Qazvini, Tarikh-I Jahangusha, 3 vols. (London, 1912, 1937) 138. 
The periodic raiding and looting of the Arab Bedouin had been a part of the life of many of the settled communities of these regions for centuries. Writing as early as the sixth century the chronicler, Joshua the Stylite, laments the curse of the nomad Arabs who under the banner of their Persian or Byzantine masters would launch continual raids on the cities and villages of northern Mesopotamia. The Bedouin Arabs,

crossed the Tigris, and plundered and took captive and destroyed all that they found ... to the Tayyaye on both sides the war was a source of much profit, and they wrought their will on both kingdoms. ${ }^{11}$

In Abu al-Faraj's time these Arabs and Kurds had been supplemented by equally ferocious bands of Turkomans.

And at that time [c. $1242 \mathrm{CE}]$ the Turkomans of the country of Ablastayn invaded our glorious monastery ... and they killed therein fifteen monks, the greater number of them being doctors, together with deacons and other subordinate clergy. ${ }^{12}$

In the twelfth and the thirteenth century these marauding gangs were often in the pay of one or other of the various warlords who dotted and terrorised the whole region. Brutal the Mongols might well have been but it was their might, cruel discipline and military prowess which differentiated the Chingizid hordes from the rude rabble armies and armed elements which had for so long preyed on these march lands. Massacres, looting and destruction had long been the norm and the expected behaviour of all armed bands and so often these elements appeared answerable to no one. The arrival of an army however rapacious and ruthless which operated under a perceivable command structure would have to have held the potential for hope. Systematic oppression can better be countered than wanton depredation.

Bar Hebraeus early in his reportage of the Mongols, catalogues their laws and the strictures governing their behaviour. First among those rules of conduct, to be observed during initial contacts with

11 J.B. Segal, 21. "Syriac Chronicles as source material for the history of the Middle-East," cited in Bernard Lewis \& P.M. Holt (eds.), Historians of the Middle-East (London: Oxford University Press) 249.

12 Bar Hebraeus, The Chronography, 408. 
their enemies, was the necessity of forewarning the victims of the consequences of resistance.

When [the Mongols] have need to write any letter to the rebels, and they must send an envoy, let them not threaten them with the great size of their army and their numbers, but let them say only, If ye will submit yourselves obediently ye shall find good treatment and rest, but if ye resist-as for us what do we know ? [But] the everlasting God knoweth what will happen to you. And in such behaviour as this the Mongols' confidence in the Lord showeth itself. And by that they have conquered and will conquer. ${ }^{13}$

In fact the icy pronouncement of these famous words:

Va agar digar kunad [kunid] ma chi danim kbudai danad!14

(and if he [you] should do otherwise, what do we know [of the consequences], God knows!)

did little to quell people's fears upon encountering their fearsome foes from the east.

\section{THE EARLIER YEARS}

[10] Certainly this awful greeting caused panic in Bar Hebraeus' home town of Malatya and the result was a general exodus of the population to Aleppo. But for an accident with their pack-mules whilst preparing to leave, the family of Aaron, a distinguished physician of Jewish descent, would also have joined the popular flight from Malatya c. 1243 CE. The mishap was to prove fortunate for when in the following year the Mongol general Shawer Noyen camped in the town after falling sick, Aaron was summoned to his side in order to minister to his medical needs. As a result of his services Aaron was retained by the Mongol though eventually along with his family he was able to move to Antioch. ${ }^{15}$

This early contact with the Mongol elite bode well for Aaron's son Gregory, an avid scholar from an early age, who was later able

${ }^{13}$ Bar Hebraeus, The Chronography, 354.

14 See Ata Malik Juvaini, Genghis Khan, 26, n. 4, \& 716 ; 'Ala al-Din Ata Malik Juwayni, Tarikh-i Jahangusha, I, 18 \& III, 265.

15 Ernest Wallis Budge, introduction in Bar Hebraeus, The Chronography, xvii. 
to display his erudite knowledge of his eastern rulers' background, traditions and culture and fully exploit his access to the libraries and court circles of Hulegu's capital, Maragha.

[12] Though their stay in Antioch was only short, it coincided with a time when relations between the Syrian Orthodox Church and the Franks were at their best. Antioch was then under the command of Prince Bohemond V whom the Syrian Orthodox Patriarch Ignatius II had greatly impressed with his theological discussions with Dominican monks in Jerusalem. So cordial were relations that it is said that Bohemond allowed the construction of an official residence and church with cells for the patriarch in the higher, more select area of the city. ${ }^{16}$

[13] Yohannan [John] Ibn al-'Ibri, Bar 'Ebhraya, Abu al-Faraj, Bar Hebraeus (1225-86 CE) was born into a prosperous region watered from the Euphrates, rich in a wide variety of crops and resplendent in fruits, with a climate said to be most salubrious, centred on the city of Malatya. "It is a large town, with an excellent climate, and running waters, and extensive pastures; its crops being corn, cotton, grapes and much fruit." 17

Malatya had been a centre for the Syrian Orthodox Church since the tenth century when the Byzantine Emperor Nicephorus Phocas had encouraged these Christian Syrians to rejuvenate what was then a decimated war front, and to establish their patriarchal seat in the region. By the eleventh century the Syrian Orthodox Church had instituted bishoprics throughout the east and southeastern lands of Anatolia as far north as Erzindjan and were active in trade and commerce and had gained a reputation for their physicians. ${ }^{18}$ On his tombstone in the Church of the Monastery of Mar Mattai near Mosul, is inscribed in Karshuni (Arabic written in the Syriac alphabet) the following: "This is the grave of Mar

${ }^{16}$ B. Abbeloos \& Th. I. Lamy (eds.), (Chron. Eccl.) Gregorii Bar Hebraei Chronicon Ecclesiasticum, 3 vols. (Louvain, 1872, 1877) Vol. 1, 653 \& 667. cited in H. Teule, "Bar Hebraeus' Syriac \& Arabic Secular Chronicles," in East \& West in the Crusader States (Leuven, 1996) 40.

${ }^{17}$ Hamdallah Mustawfi, Nuzhat al-Qulub, tr. G. Le Strange (London: Luzac \& Co., 1919) 98-9. Persian text, London, 1915, p. 99.

18 Speros Vryonis, The Decline of Medieval Hellenism in Asia Minor (Berkeley/Los Angeles: University of California Press, 1971) 51-2. 
Gregory John, and of Mar Sawma his brother, the children of the Hebrew on Mount Elpeph."19

Wallis Budge has suggested that he may have adopted the name Gregory after he was consecrated a bishop twenty years after his father christened him John. Wallis Budge further suggests that the Arabic epithet, Abu al-Faraj, "Father of what is pleasing (?)" which Bar Hebraeus himself adopted might indicate that whereas his father is commonly assumed to have been a Jewish physician it could be that his mother had been an Arab. The meaning behind the epithet is a mystery and whether it refers to the Bab al-Faraj of Aleppo, a city where the cleric dwelt or to his good works, or to his extensive writing remains open to conjecture.

Since at least 1927 doubts have been thrown on the assumption that Bar Ebroyo's father was Jewish, with suggestions that his descent is more likely to have been from a noble Christian family. The confusion, it is claimed, was caused by the commonly Jewish name of Aaron which, being of biblical origin, was not uncommonly found among Christians. "Bar Ebroyo" so often rendered as "Bar Hebraeus" should rather be interpreted as "Son of Ebra" which would indicate either that one of his ancestors was born while crossing the Euphrates or that the ancestor hailed from the village of Ebra, a village on the banks of the Euphrates. These views were first raised by Afram Barsaum in 1927 in a paper in Arabic, "Bar Hebraeus: was he of the Jewish Race?" 20

In the Encyclopaedia Iranica, Herman Teule states quite unequivocally that Bar Hebraeus was not born of Jewish origin. ${ }^{21}$

For another source for these doubts the Syrian Orthodox scholar, the Rev. Joseph Tarzi, cites a poem attributed to the cleric, Ibn al-e ebri himself.

If the Lord called Himself Samaritan, do not be ashamed if they call you Bar Ebroyo. For this name's

${ }^{19}$ Cited in by Ernest Wallis Budge, introduction in Bar Hebraeus, The Chronography, xvi. see Badger, The Nestorians and their Rituals, vol. I, 97.

${ }^{20}$ For bibliographical details of Barsaum's work (p. 282, under 1927) and a survey of works related to Bar Hebraeus see, Jean-Maurice Fiey, "Esquisse d'une Bibliographie de Bar Hebraeus (+1286)," Parole de l'Orient XIII (1986): 279-312.

21 See "Ebn al-'Ebri," in H.G.B. Teule, Encyclopedia Iranica, vol. 7 (London: Routledge \& Kegan Paul, 1997). 
origin is of the river Euphrates and not of a disgraceful faith or a language. ${ }^{22}$

During his youth, attached to the Il-Khan general, Shawer Noyen's court through his father's duties as a physician, Bar Hebraeus was enabled to continue his scholastic life which brought him under the influence of the Syrian Orthodox Church. While based in Antakya (Antioch) he received a visit from the Patriarch David Ignatius Saba, which is indicative of the social status the family had attained through their position with the Mongols. Shortly afterwards, at the age of seventeen, the son of Aaron the Mongols' physician, became a monk and entered the life of a hermit. Mysticism and the life of the ascetic were to remain central to the spirit of this "love-sick seeker of the Beloved"23 throughout his life though as he recounts in his Book of the Dove, a spiritual guide for the solitary monk, he travelled this troubled path without the guidance of a master. ${ }^{24}$

However his meditations were interrupted and the worldly affairs of the Syrian Orthodox Church ${ }^{25}$ soon came to dominate his earthly life. Leaving Antakya he travelled south with Salibah bar Ya'qub Wagih, to the coastal city of Tripoli where they studied rhetoric and medicine under Ya'qub of the Church of the East. From Tripoli they were summoned by the Patriarch Ignatius II to be consecrated as bishops of Akko and of Gubos near Malatya. Bar Hebraeus was ordained as Bishop of Gubos on the Festival of the

22 Joseph Tarzi, "Maphryono Mar Gregorious Youhanon Bar Ebroyo."

[http://www.netadventure.com/ soc/Biogr/BarHeb/TarziBar.html] 23 "All those who are burning from love and sick from affection reveal their secrets to her [the beloved] and she slakes their thirst." Bar Hebraeus' Book of the Dove, tr. A.J. Wensinck, E.J. Brill (Leyden, 1919), Introduction, p. 4.

${ }^{24}$ His book was intended as "psychic medicine, to give instructions concerning the behaviour of those patients [mystic monks] who are without or far from a leader; especially in this our age, in which the Syriac world is bereft of an Initiated, who has personally experienced the straightness of the way leading to the kingdom and the narrowness of the gate giving entrance to it. It is therefore our aim to give this sort of clear and simple instruction." ibid., 3.

${ }^{25}$ See Wright, A Short History, 265-8; Wallis Budge, introduction in Bar Hebraeus, The Chronography, xvii-xxviii. 
Day of the Redeeming Cross, 14 September 1246 CE at the age of twenty. Many years later, approaching death, the then ageing Maphrian, saw great astrological significance in this date which along with his birth in $1226 \mathrm{CE}$, his appointment as Maphrian and his expected and actual death in 1286CE he had found reflected in the stars.

In that year in which Kronos and Zeus were in conjunction in the Zodiacal Sign of Aquarius I was born. And twenty years after, when they were in conjunction in the Zodiacal Sign of Libra, I was ordained bishop. And twenty years after, when they were in conjunction in the Zodiacal Sign of Gemini, I undertook the office of Maphrian. And after another twenty years, when they will be again in conjunction in the Zodiacal Sign of Aquarius, I think that I shall go out of this world. ${ }^{26}$

Before Bar Hebraeus had succeeded to Maphrian of the East there had been a bitter schism within the Church between Dionysius (Aaron Angur) and John bar Macdani both of whom wished to take on the local leadership of their church following the death of the Patriarch Ignatius II. After Dionysius whom Bar Hebraeus had backed was installed, the Maphrian Salibha, ${ }^{27}$ the onetime friend from Tripoli, arrived in Aleppo and began spreading gold and influencing people not only amongst the faithful but in the circles of the then government of al-Malik al-Nasir Yusuf in Damascus.

And he [Salibha] made himself ready and went to Damascus, and he undertook to pay as much gold as Dionysius had undertaken to pay, and he obtained a patent (i.e. authority from the government) for the deposition of Dionysius and for the proclamation of Mar John bar Macdani. ${ }^{28}$

26 Cited in Wallis Budge, introduction in Bar Hebraeus, The Chronography, xx, from Bar Hebraeus' Chronicum Ecclesiasticum, II, cols. $432 \mathrm{f}$.

${ }^{27}$ From Akko he had been transferred to Aleppo where he took the name Basil, before being made Maphrian Ignatius in December 1252 by the Patriarch John bar Ma dani. He died in 1258. see Wright, A Short History, 267.

${ }^{28}$ Bar Hebraeus, The Chronography, xviii. 
However later still, an envoy from the Mongols, Amin al-Din Mubarak of the Church of the East, tried to prevail on Malik Nasir in Damascus to reverse his ruling in favour of Dionysius' rival which though unsuccessful caused John bar Ma'dani to retreat to the Cilician court of the Armenian King Hatoum out of fear of the approaching long arm of the Mongols. Eventually Gregory Abu alFaraj representing Dionysius succeeded in Damascus where the Mongols' envoy had failed and a new patent of authority was delivered to Dionysius. Hearing of the matter Maphrian Ignatius [Salibha] retired to Tripoli where he expressed his disillusionment with his ministry and his intention of devoting the rest of his life to the service of the sick. He died in $1258 \mathrm{CE}$, a time of great turmoil for the people of the whole region, and it would be six years before a successor was proclaimed.

The wasted Church of the East remained a widow for the space of six years. Moreover, for three years before the death of Salibha the Maphrian, the Church had been deprived of a Father-General. Therefore the Synod of the pious bishops having assembled in Cilicia, they appointed to be Patriarch Mar Ignatius or Rabban Isho, the Archimandrite of Gawikhath, and they also proceeded to the election of the Mapbrian. And a few days after the consecration of the Patriarch the pious bishops and the Patriarch assembled in Sis of Cilicia, and they summoned Gregory, that is Abu al-Farag, the son of Aaron. And on the first day of the week, on the 19th day of the month of the Later Kanon (i.e. January) 1264 CE ... they proclaimed him Maphrian of Tagrith and the East. ${ }^{29}$

This time the Church leaders did not turn southward toward Damascus to obtain endorsement for their appointments but instead immediately sought out the court of the new King of Kings, Hulegu Khan, and it so happened that the appointment of Bar Hebraeus as Maphrian coincided with the establishment of a new order in the lands of Persia, Rum and upper Mesopotamia and an era of relative stability for many of the people of those regions.

And the Patriarch with the Maphrian and the rest of the bishops made ready and went to tender homage to the

${ }^{29}$ Bar Hebraeus, The Chronography, xx. 
king of kings [Hulegu], and (one) Patent was written for the Patriarch, and another for the Maphrian. ${ }^{30}$

From Bar Hebraeus' own words it would appear that the next year was a time of general rejoicing as the new Maphrian, basing himself in Mosul and Baghdad, travelled throughout his diocese ordaining new monks, bishops and deacons, and blessing and reassuring his congregation.

\section{BAR HEBraeus THE WRITER}

[24] Bar Hebraeus rose not only to be a giant of the intellectual world of the mediaeval Middle East but has maintained his stature to the present day. His prodigious output of learned books, his very active life as a high ranking ecclesiastic, the universal reverence expressed toward him and his remarkable aptitude for languages and erudition have ensured his memory a fame far beyond the confines of the Eastern churches. His Chronography alone should have put lie to the oft repeated claim that

the literature of Syria is ... not an attractive one. ... the characteristic of the Syrians is a certain mediocrity. They shone neither in war, nor in the arts, nor in science. ... There was no al-Farabi, no Ibn Sina, no Ibn Rushd, in the cloisters of Edessa, Ken-neshre, or Nisibis. ${ }^{31}$

[25] He was brought up in Syriac and Arabic and presumably Hebrew but he was to acquire mastery of many more languages later in life. In his introduction to his Chronography, Bar Hebraeus relates that he was able to access the works of Syrians, Saracens and Persians in the Il-Khans' libraries. 'I, having entered the library of the city of Maragha of Adhorbijan, have loaded up this my little book with narratives which are worthy of remembrance." 32

$\mathrm{He}$ readily acknowledges his indebtedness to Ala ad-Din Ata Malik Juwayni in his Chronography and it must be inferred that he was fluent enough in Persian to appreciate and understand the governor of Baghdad's often flowery hand.

${ }^{30}$ Bar Hebraeus, The Chronography, xxi.

31 William Wright, A Short History of Syriac Literature (London: Adam \& Charles Black, 1894) 1-2.

32 Bar Hebraeus, The Chronography. 


\begin{abstract}
[Juwayni] was exceedingly skilled in doctrines (or, learned subjects), and had an adequate knowledge of the poetic art. And he composed a marvellous work in Persian on the chronology of the kingdoms of the Saljuqs, and the Khwarazmians, and the Ishmaelites, and the Mongols; what we have introduced into our work on these matters we have derived from his book. ${ }^{33}$
\end{abstract}

He had direct contact with the Mongol court from an early age and would likely have become at least conversant in Mongolian, and his easy knowledge of their history, traditions and laws suggests an access to documentary material which would require conversancy in Uighur. In many of his more learned treatises he quotes extensively from Greek writers. Though many of these classical works had been translated into Syriac and Aramaic it is widely thought that Bar Hebraeus would have been acquainted with them in the original Greek. ${ }^{34}$

In his book "The Laughable Stories" written toward the end of his life are collected stories from a wide variety of sources with quotes from Persian, Indian, Arab, and Greek sages the works with which he could have had familiarity though it has been suggested that in fact Bar Hebraeus relied on translated Arabic sources for many of these tales. ${ }^{35}$ Wallis Budge concluded that in addition to the above Abu al-Faraj was conversant with Chinese, had a working knowledge of Armenian and was acquainted with the dialects of Turkestan, Mongolia, and western China. However there is no real evidence that he knew any Chinese at all since even the Yüan rulers are thought to have only acquired even a rudimentary knowledge of their subjects' language later in the 14th century.

[29] Bar Hebraeus' great erudition and considerable intellectual output is evidenced by even a cursory glance at the list of the written works which bear his name. His brother Bar Sawma listed some 32 books from a variety of genres in the biography of his sibling. The subjects Abu al-Faraj tackled included books on theology, philosophy, history, medicine, mathematics, grammar, astrology, fables, stories and legends. In his Hewath Hekmetha, or "Book of the Butter of Wisdom" he elucidates the works of Aristotle; in

${ }^{33}$ Bar Hebraeus, The Chronography, 473.

34 See W. Budge's introduction in Bar Hebraeus, The Chronography, xlv.

35 See U. Marzolph, Oriens Christianus 69 (1985): 81-125. 
1279 CE he wrote his treatise on cosmology and astronomy, "Book of the Ascension of the Intellect" 36 which was to be used in conjunction with the tables of his Astronomical Almanac; "The Book of Indications and Prognostications" is a Syriac translation of Ibn Sina's Theoremata et Exercitationes, a study of logic, physics and metaphysics; "The Lamp of the Sanctuary" details the twelve basic principles on which his church was established; "The Book of the Dove" is a text book for hermits and ascetics; and "Ethicon" composed in 1279 in the Il-Khanid capital, Maragha, ${ }^{37}$ contains sections on exercising the body and the spirit, purification and adornment of the soul, and the merits of fasting, manual labour, prayer and study. In addition to composing these weighty tomes, Bar Hebraeus also gained great admiration among his fellow Syrian Orthodox believers for his poetry, and his marvellous collection of humorous tales compiled and written up in his later years. These works reflect a more human, less serious side to his complex personality. In justifying the variety of the material to be found in his "Book of Laughable Stories" Bar Hebraeus could have been justifying his life's work.
in the tabernacle of wisdom every kind of thing is necessary, nothing whatsoever that in a natural way sharpeneth the intelligence, and enlighteneth the understanding, and comforteth and rejoiceth the mind which is sorrowful and suffering, should ever be rejected. ${ }^{38}$

His Chronography had achieved such fame in his lifetime that he was entreated to translate the work into Arabic for the benefit of his many Arabic speaking devotees. This so-called Arabic translation of his history Ta'rikh al-Mukbtasar al-Duwal, was completed but for three leaves just before his death and contains details of Muslim writers and figures not mentioned in his earlier Syriac history. For these reasons the later Arabic version cannot be dismissed as an abridged or glossed version of the Syriac chronicle. Much has been made of the differences between these two versions

${ }^{36}$ F. Nau (ed. \& tr.), Le Livre de l'Ascension de l'Esprit sur la Forme du ciel et de la Terre, 2 vols. (Bibl. De l'École des Hautes Études, Sciences philologiques et historiques 121; Paris, 1899-1900).

${ }^{37}$ See H. Teule, introduction in Gregory Bar Hebraeus' Ethicon, Memra I (Lovanii in Aedibus E. Peeters, 1993) ix-x.

38 Bar Hebraeus, The Laughable Stories, tr. E.A. Wallis Budge (London: Luzac \& Co., 1897; reprint New York: AMS Press, 1976) 186. 
of his history and significance interpreted from the divergences found in the stories related within them. The Arabic version cannot be regarded as a translation from the earlier Syriac version nor can the Arabic title, Mukbtasar, which translates as "summary" be accepted as an accurate description of the work since this later version contains much detail missing in the former. One explanation for the differences in these two versions put forward by Anneliese Lüders in a doctoral thesis supervised by the eminent Bertold Spuler, ${ }^{39}$ was that the two histories were consciously composed for two religiously and politically distinct audiences, one Arabic speaking and presumably Muslim and the other Syriac speaking and therefore Christian. In contrast to this explanation L. Conrad ${ }^{40}$ advanced the theory that the Arabic version was written from a Christian point of view and that it was composed for the Christians of the time the majority of whom were unable to read liturgical Syriac and used Arabic for their everyday needs. "There can be no doubt that Bar Hebraeus continued to write with Christian concerns and with a Christian audience in mind." 41 Rejecting both these theories Herman Teule has advanced a far simpler and far more plausible explanation for the divergences in Bar Hebraeus' histories. After careful analysis of the texts in particular with regard to those relating to the Crusades, Teule has shown that the two histories relied on different source materials and that the differences and omissions reflect these differing sources. For significant parts of his Syriac chronology Bar Hebraeus relied heavily on the histories of Michael the Syrian ${ }^{42}$

39 A. Lüders, Die Krenzzüge im Urteil syrischer und armenische Quellen (Berliner Byzantinistische Arbeiten 29; Berlin, 1964), cited in H. Teule, "Bar Hebraeus' Syriac \& Arabic Secular Chronicles," in D. Ciggaar, H. Teule (eds.), East \& West in the Crusader States, (Leuven, 1996) 43.

${ }^{40}$ L. Conrad "On the Arabic Chronicle of Bar Hebraeus: His aims and audience," papers read at the IV th Conference on Christian Arabic Studies, Cambridge, Sept. 1992; published in Parole de l'Orient XIX (Université Saint Esprit, Kaslik, Lebanon, 1994) 320-78.

${ }^{41}$ Conrad, "On the Arabic Chronicle of Bar Hebraeus," 337.

42 J.B. Chabot (ed. \& tr.), Chronique de Michel le Syrien, Patriarche jacobite d'Antioche, 4 vols. (Paris, 1900-10). 
whereas in his Arabic version his source was the al-Kamil fi'l-Ta'rikh of al-Athir. ${ }^{43}$

Other sources were of course used and consulted but in essence the differences in Bar Hebraeus' two versions of history were due simply to the fact that he used new original source material in the later version rather than attempt to translate his own work directly from Syriac to Arabic. What does become clear is that the facts were not presented in a manner presumed pleasing to an anticipated audience but were reflective of the words and attitude of the original source. ${ }^{44}$

\section{The Reluctant Cleric}

Unlike other Christian historians of this time, Bar Hebraeus does not revel in any perceived bias that Hulegu might have held for Christians as against Muslims. It was well known that the King of King's wife, Doquz Khatun, ${ }^{45}$ was a Kerayit princess of the Church of the East and was able to prevail upon her Buddhist husband to treat Christians well. It was even claimed that she was descended from the Biblical three wise men and that she had had many new churches built and "the temples of the Sarasens to be beton downe. (sic)" 46 The contemporary Armenian historian, Stephannos Orbelian, even portrayed Hulegu and Doquz Khatun as the Constantine and Helen of the age. ${ }^{47}$ Bar Hebraeus was aware of her tribe's long Christian roots ${ }^{48}$ and of her attachment to his faith,

43 C.J. Tornberg (ed.), Ibn el-Athiri Chronicum quod perfectissimum inscribitur, 12 vols. (Leiden, 1853-67, and reprinted Beirut, 1965-6).

${ }^{44}$ H. Teule, "Bar Hebraeus' Syriac \& Arabic Secular Chronicles."

45 On Dokux Khatun see Charles Melville, Encyclopedia Iranica, vol. 6 (London: Routledge \& Kegan Paul, 1997).

46 Hetoum, A Lytell Cronycle, tr. Richard Pynson (University of Toronto, 1988) 176.

47 Stephannos Orbelian, Histoire de la Sioune, tr. Marie Brosset (St. Petersbourg, 1864) 234-5. See also J.M. Fiey, "Iconographie Syriaque Hulagu, Doquz Khatun ... et Six Ambons,” Le Muséon (1975): 59-64.

${ }_{48}$ Bar Hebraeus, The Chronography, 184. "And in this year [1007] the people of one of the tribes of the Inner Turkaye in the East, which is called Kirith, believed in Christ, and they became disciples and were baptised through the miracle which was wrought in connection with their king." See Erica Hunter, "The Conversion of the Kerait to Christianity in 1007," Zentral-Asiatische Studien 22 (1989-91). 
"Tokuz Khatun, the believing queen and lover of Christ"49 but in his Chronography he does not dwell either on the favoured treatment he himself received nor of any obvious partiality that the Mongols might have shown to the Christians, indeed he objectively catalogues the fatally harsh treatment the Christians on occasion received. ${ }^{50}$

It is Bar Hebraeus' comparative objectivity and simplicity of style which distinguishes him from other Christian chroniclers of the time such as Vardan, Hetoum, Grigor, Orbelian and Kirakos. His great tolerance of others, reflective of his introspective and mystical character, earned him friends and respect from all communities so much so that it was his Arab neighbours who beseeched him to translate his Syriac political history into Arabic for their appreciation.

His life as Maphrian of the East forced upon him reluctant involvement in the various political and confessional intrigues of his church, as he recounts in his Chronicum Ecclesiasticum, ${ }^{51}$ but writing in his mystical treatise "The Book of the Dove" where the man rather than the cleric speaks he makes plain his aversion to such a life.

I hated other sorts of knowledge [other than his study of Greek wisdom and mysticism], though I had to occupy my thoughts superficially with some of them, not for my own sake, but for the sake of others who wished to profit by me. During this space of time, many offenses made me miserable and caused me to stumble. ${ }^{52}$

In this treatise written for others who like him found themselves embarking on the mystical quest without an initiated guide, can be heard the voice of humility and compassion as well as the rapture of the "lover" and of one who has felt the "divine impulse moving in the mind of man." 53 He explains that early in his training as a cleric he was able to discern the fundamental unity of Christian belief and perceived the perpetual doctrinal disputes

${ }^{49}$ Bar Hebraeus, The Chronography, 435.

${ }^{50}$ Ibid., 433.

51 Ibid., $\mathrm{xx}-\mathrm{xxviii}$.

${ }^{52}$ Bar Hebraeus' Book of the Dove, tr. A. J. Wensinck, E. J. Brill (Leyden, 1919), Introduction, p. 61.

53 Bar Hebraeus' Book of the Dove, 5. 
and disquisition he was forced to engage in, as not only tiresome but insidiously detracting from the true expression of his church, divine love.

I became convinced, that these quarrels of Christians among themselves are not a matter of facts but of words and denominations. ... And I wholly eradicated the root of hatred from the depth of my heart and I absolutely forsook disputation with anyone concerning confession. ${ }^{54}$

He did not put great store in those who put recitation and knowledge of the scriptures above direct experience.

As hunger is not satisfied by water, nor thirst by bread, so the Initiated, who wishes to look within the Sinaitic cloud [the Divine], gains small profit by hearing the Scriptures being read. ${ }^{55}$

and he cautioned that mere "reciting of the scriptures and steady labour" do not the true Initiate make.

For many have laboured strenuously, but because they have not laboured with intelligence, they have not attained the way of truth, nor reached the harbour of life. ${ }^{56}$

Though not explicitly stated, this sense of profound tolerance which pervades Bar Hebraeus' "Book of the Dove." was probably extended not only to the adherents of the schisms within his own church but to the disciples of other faiths that he would have become intimately connected with. In his introduction to his translation of the "Book of the Dove," A.J. Wensinck demonstrates at length Bar Hebraeus' indebtedness to the Muslim mystics and in particular to al-Ghazzali not only in the organisation of his material ${ }^{57}$ but also in the aims particularly of his book Ethicon. ${ }^{58}$ The mystic system expounded by Abu al-Faraj reveals clear links with his Syriac predecessors but the influence of Ghazzali and

${ }^{54}$ Bar Hebraeus' Book of the Dove, 60.

55 Ibid., 63.

56 Ibid., 65.

${ }^{57}$ Ibid., introduction, pp. xvii-xviii, cxi-cxxxvi.

58 Gregory Bar Hebraeus, Ethicon, tr. Herman Teule (Lovanii In Aedibus E. Peeters, 1993). 
other Muslims seekers is so marked as to suggest his intimacy with the teachings of these masters, and the resulting "eastern syncretism," a term Wensinck employs to describe the spiritual attitude of the times. Bar Hebraeus goes some way to acknowledging this indebtedness when he states, "if [the Lord] had not led me to look in the writings of the Initiated ... occidental and oriental ... I would ere long have despaired of psychical, if not of bodily life." 59 In Etbicon he demonstrates not only the unmistakable pervasive influence of al-Ghazzali but of his own tolerance and balanced attitude to views not in accordance with his own. Discussing the merits of music and dance for the pious life ${ }^{60}$ he sets out clearly the three prevailing views on the subject though admittedly he leaves the student in no doubt of his own "true view" which take the middle ground between those would have a total prohibition and those such as the followers of the Maulana of Konya who believe that music and dance are intrinsic to the mystical life.

Bar Hebraeus spent the last years of his life in Maragha, the IlKhanid capital. Maragha had already established connections with the Syrian Orthodox Church when Rabban Simeon first entered Hulegu's service. Part of his annual 5000 dinar income was provided for by Maragha. ${ }^{61}$ Bar Hebraeus had visited the city from Tabriz as early as 1268 in which year he had first been exposed to the books of Euclid and again in 1273 when he studied the thirteen astronomical volumes of the Almegest of Ptolemy. ${ }^{62} \mathrm{He}$ had early begun planning a programme of church construction in West Azerbijan. In 1279, the year of Abu al-Faraj's return to Maragha, Qutai Khatun, the mother of Tegudar Ahmad (Il-Khan 1282-4), had revived the Christian procession of the Epiphany which involved the blessing of the waters of the river Safi. The annual procession had ceased to be held because of conflicts between the Muslims and Christians but the presence of one the royal family in person ensured the success of the revived festival.

[Qutai Khatun] came in person to the city of Maragha, and commanded the Christians to go forth according

${ }^{59}$ Bar Hebraeus' Book of the Dove, Introduction, p. 61.

${ }^{60}$ Bar Hebraeus' Book of the Dove, 118-122.

${ }^{61}$ Bar Hebraeus, The Chronography, 437.

${ }^{62}$ J.M. Fiey, Chrétiens Syriaques sous les Mongols (Louvain, 1975) 99. 
to their custom with crosses suspended from the heads of their spears. And having gone forth the Divine Grace visited them, and the strength of the cold diminished, and the grass prospered, and the winter possessed the characteristics [favourable] for herbage. And the Mongols had joy in keeping their horses in condition, and the Christians in the triumph of their faith. ${ }^{63}$

According to Assemani, in 1282 Ahmad Tegudar had granted Abu al-Faraj a licence to build churches in Azerbijan, Assyria and Mesopotamia, ${ }^{64}$ and both Tabriz and Maragha benefited from his industry. He had been reluctant to leave Mosul for the Mongol capital knowing that the move might be his last. However, his brother who feared lest the Maphrian's own prophecies foreseeing his death in his sixtieth year should come about at the hands of "thieves and robbers" had insisted that he should abandon the lawless march lands of "Syria" and seek the safety of the Il-Khanid metropolis where he could find sanctuary in his own church and monastery. So tranquil and conducive to intellectual activity was the Il-Khanid capital that the ageing cleric was able to complete not only his great work, the Ethicon, but also a scientific work inspired and helped no doubt by the proximity of the Rasad-e Khan of Nasir al-Din Tusi, the Book of the Ascension of the Intellect. ${ }^{65}$

It is claimed that the remains of his church and monastery can still be seen today on the outskirts of the leafy town of Maragha. This church on the western face of a hill overlooking the city would have been ideal for the ageing cleric whose great interest in the stars has already been noted. The entrance to the caves which formed the body of this church lay only thirty or forty metres beneath the famous observatory of Maragha, the Rasad-e Khan, which Hulegu had had constructed for his greatly respected advisor

${ }^{63}$ Bar Hebraeus, The Chronography, 460. Cf. Fiey, Chrétiens Syriaques sous les Mongols, 38.

64 Bibliotheca Orientalis, vol. II, 258. Cited in John Bowman \& J.A. Thompson, "The Monastery-Church of Bar Hebraeus at Maragheh in West Azerbijan,” Abr-Nabrain, vol. V (1964-5), E.J. Brill (Leiden, 1966) 38.

${ }^{65} \mathrm{Nau}$, Le Livre de l'Ascension de l'Esprit sur la Forme du ciel et de la Terre. 
and friend of Bar Hebraeus, Nasir al-Din Tusi. ${ }^{66}$ That a "new monastery" and a "new church" existed at this time in Maragha is attested to in Bar Hebraeus' Chronicum Ecclesiasticum. ${ }^{67}$ Well aware that his time had come for he had seen it in the night sky, the dying Abu al-Faraj "never ceased from telling stories with laughter and a cheerful face. [Suddenly] he went out like a lamp."68 The Uighur Catholicos of the Church of the East ordered the bazaars of Maragha closed and there was great mourning in all the communities when the news of the death became known.

\section{THE LaST LaUgH}

[41] It was in the last years of his life that he composed his "Laughable Stories" which can perhaps be seen as the link between the tireless erudite scholar and the humble mystic and witness to the conceits of his too human nature. It was a book written as a "consolation to those who are sad, and a binding up (of spirit) to those who are broken, and an instructive teacher to those who love instruction, and a wonderful companion to those who love amusement," ${ }^{9}$ not just for his Syrian Orthodox followers but for all the people of the world as is evinced in the Prologue.

And let this book be a religious friend to the reader, whether he be Muslim, or Hebrew, or Aramean, or a man belonging to a foreign country. And let the man who is learned ....and the man that babbleth conceitedly ... and every other man chose what is best for himself ... for in this way the book will succeed in bringing together the things which are alike, each to the other. ${ }^{70}$

${ }^{66}$ For a description and explanation of this "church" see Bowman \& Thompson, "The Monastery-Church of Bar Hebraeus," 35-61. For an alternative view as to the nature of these caves see W. Ball, "Two aspects of Iranian Buddhism," Bulletin of the Asia Institute of Pablavi University 1-4 (1976): 103-63; "The Imamzadeh Ma'sum at Vardjovi. A rock-cut IlKhanid complex near Maragheh," Archaeologische Mitteilungen aus Iran 12 (1979) 329-40.

${ }^{67}$ Chronicum Ecclesiasticum, III, 443; cited in H. Teule, introduction in Gregory Bar Hebraeus' Ethicon, xi, n. 12.

${ }^{68}$ Bar Hebraeus, The Chronography, xxix.

${ }^{69}$ Bar Hebraeus, The Laughable Stories, iii.

${ }^{70}$ Ibid., iii-iv. 
[42] The themes include women's rights as in story 515 which recounts two women explaining the injustice of men having free access to young prostitutes, something denied them, being due to the fact that "the kings, and the judges, and the lawgivers are all men; and they have therefore acted the parts of advocates of their own causes and have oppressed the women," 71 dreams and divination, the powers of which the Maphrian certainly believed, to wisdom as in the story of the gazelle who explained why the pursuant dog would never catch her "because I run for my life, but thou for thy master." 72 Sometimes cynical, sometimes lewd, often amusing, the stories pillory kings, beggars, tradesmen, priests, philosophers and fools and in the tradition of other medieval collections of tales, the "Langhable Stories" provide a kaleidoscopic vision of Bar Hebraeus' medieval world. It also provides a view of the Maphrian's essential compassion, empathy with his fellow man and pleasure in the life he saw around him.

Bar Hebraeus has survived not only because of the irreplaceable value of his histories, their detail and the evidence of events witnessed first hand but because his accounts are uncommonly objective and that the honesty expressed in his more esoteric writings has been allowed to permeate his historical work. Bar Hebraeus' main vocation in life was his spiritual quest and all else was secondary. His moral convictions were binding on all aspects of his life. He had learnt humility early in his search for enlightenment. "I resembled a man who is immersed in the ocean and stretches forth his hands towards all sides in order to be saved." $73 \mathrm{He}$ did not rate his success in the transient world so highly. He judged himself so severely that he must have been hesitant about judging others. "I teach but I do not learn; I write but I have neglected; I preach but I do not practice; I admonish but I have sinned." 74 In the "Book of the Dove." he clearly expresses his attitude toward flattery, sycophancy and lies in a chapter devoted to "Offences of the Tongue."

Speech which is indirectly sinful consists of tales concerning the glory, the prevalence and the opulency

\footnotetext{
${ }^{71}$ Bar Hebraeus, The Langhable Stories, 136.

72 Ibid., 92.

${ }^{73}$ Bar Hebraeus' Book of the Dove, 61.

74 Ibid., 30.
} 
of wicked people ... The end of the wicked shall be destruction, in this world and in the world to come ... Flattery. The flatterer falls into four evils ... He who is flattered falls into two damages. ${ }^{75}$

His praise of his Mongol masters is measured and in no way excessive. The Syrian Orthodox Church undoubtedly prospered and experienced a period of stability under Hulegu and Abaqa, "And the Church acquired stability and protection in every place."76 Bar Hebraeus' claim that Abaqa "was beloved by all the peoples who were under his dominion" (where it should be noted that he speaks of the "peoples' in the plural and not of just his own people) is an assertion that can be accepted at face value. Whereas the Persian court historians such as Juwayni, Wassaf and Rashid alDin might have expected that their works would be studied and read by their Mongol overlords there was not the same likelihood that the Syriac tomes would have found as wide an audience. Bar Hebraeus was writing for posterity in order to keep the Syriac language alive and for the education of future generations and not for the glory of any one king, leader, sect or group. He had attended the Diwan of the Il-Khans but he was not of the court. He had access to their libraries, a privilege he could not have failed to greatly appreciate, and must have met while in Maragha many of the great figures of the time who were attracted to the capital in Azerbaijan including the philosopher and astronomer Nasir al-Din Tusi $^{77}$ to whom he devoted a warm and laudatory paragraph in his Chronography. ${ }^{78}$ Bar Hebraeus could not have approved of all the actions of his earthly masters but neither did he approve of the striving of anyone after the transitory treasures of the material world. The brutality of the Mongols was only worse than that of other conquerors, warlords and bandits in that it was carried out more thoroughly and systematically and conducted on a larger scale and, it would appear, more cold-bloodedly than that of other armies and armed elements. But Bar Hebraeus must have felt that

75 Bar Hebraeus' Book of the Dove, 12-4.

${ }^{76}$ Bar Hebraeus, The Chronography, 437.

77 See J.A. Boyle, "The Longer Introduction to the Zij-I-Ilkhani of Nasir al-Din Tusi," Journal of Semitic Studies VIII (1963): 253; reprinted in The Mongol World Empire 1206-1370 (Varorium Reprints; London, 1977), ch. xxvii, p. 253.

${ }^{78}$ Bar Hebraeus, The Chronography, 451. 
some justice shone through the ruthlessness and that there did now exist the possibility of some form of recourse to legitimacy. He was certainly able to lead a full and very spiritually and intellectually active life and the comparative stability which allowed that to happen must have been due to the iron-like presence of the Mongols and the rigorous order that they imposed upon the lands of their turbulent charges. Just as his Christian predecessor, Matthew of Edessa, had mourned the passing of Malik-Shah and could foresee the period of instability which would invariably follow, so too must the Maphrian have looked wistfully to the years of the early Il-Khanate when the King of Kings had mightily wielded such reassuring power.

\section{REFERENCES}

Badger, G.P. The Nestorians and their Rituals, with the Narrative of a Mission to Mesopotamia and Coodistan in 1842-1844, 2 vols. London, 1852.

Ball, W. "Two aspects of Iranian Buddhism." Bulletin of the Asia Institute of Pablavi University. 1-4, pp. 103-63, 1976.

Ball, W. "The Imamzadeh Ma'sum at Vardjovi. A rock-cut Il-Khanid complex near Maragheh.” Archaeologische Mitteilungen aus Iran, 12, pp. 329-40, 1979.

Bar Hebraeus, tr. Ernest Wallis Budge. The Chronography of Abu'l-Faraj Bar Hebraeus. Oxford University Press, 1932; reprint APA-Philo Press, Amsterdam, 1976.

Bar Hebraeus, ed. B. Abbeloos \& Th. I. Lamy. (Chron. Ecch). Gregorii Bar Hebraei Chronicon Ecclesiasticum. 3 vols. Louvain, 1872, 1877.

Bar Hebraeus, tr. A. J. Wensinck. Bar Hebraeus's Book of the Dove. E. J. Brill, Leyden, 1919.

Bar Hebraeus, tr. H. Teule. Gregory Bar Hebraeus' Ethicon, Memra I. Lovanii in Aedibus E. Peeters, 1993.

Bar Hebraeus, tr. E.A. Wallis Budge, The Laughable Stories. Luzac \& Co., London 1897; reprint AMS Press, New York, 1976.

Bowman, John, \& J.A. Thompson. "The Monastery-Church of Bar Hebraeus at Maragheh in West Azerbaijan." Abr-Nabrain, vol. V, 1964-5. E.J. Brill, Leiden, 1966.

Boyle, J.A. "The Longer Introduction to the Zij-I-Ilkhani of Nasir al-Din Tusi." Journal of Semitic Studies, VIII. Manchester, 1963; reprint in The Mongol World Empire 1206-1370. Varorium Reprints, ch. xxvii, London, 1977.

Conrad, L. "On the Arabic Chronicle of Bar Hebraeus: His aims and audience," papers read at the IV ${ }^{\text {th }}$ Conference on Christian 
Arabic Studies, Cambridge, Sept., 1992, published Parole de l'Orient, vol. XIX, Université Saint Esprit, Kaslik, Lebanon, 1994.

Fiey, Jean-Maurice. "Esquisse d'une Bibliographie de Bar Hebraeus (+1286)." Parole de l'Orient XIII, pp. 279-312, 1986.

Fiey, Jean-Maurice. Chrétiens Syriaques sous les Mongols. Louvain, 1975.

-. "Iconographie Syriaque Hulagu, Doquz Khatun ... et Six Ambons." Le Muséon, pp. 59-64, 1975.

Grigor of Akanc," tr. R. Blake \& R. Frye. History of the Nation of Archers. Harvard University Press, 1954.

Hunter, Erica. "The Conversion of the Kerait to Christianity in 1007." Zentral-Asiatische Studien, 22. 1989-91.

Hetoum, tr. Richard Pynson. A Lytell Cronycle, University of Toronto, 1988.

Ibn al-Athir, ed. C.J. Tornberg. Ibn el-Athiri Chronicum quod perfectissimum inscribitur, 12 vols. Leiden, 1853-67 and reprinted Beirut, 1965-6.

Juvaini, Ala al-Din "Ata Malik, tr. J.A. Boyle. Genghis Khan: The History of the World-Conqueror, Manchester University Press, 1997.

Juvaini, 'Ata Malik, ed. Mirza Mohammed Qazvini, Tarikh-i Jahangusha, 3 vols. London, 1912, 1937.

Lüders, A. Die Kreuzzüge im Urteil syrischer und armenische Quellen. Berliner Byzantinistische Arbeiten, 29. Berlin, 1964.

Marzolph, U. "Sources of the Laughable Stories." Oriens Christianus 69, pp. 81-125, 1985.

Matthew of Edessa, tr. A.E. Dostourian. Armenia and the Crusades. The Chronicle of Matthew of Edessa. New York: University Press of America, 1993.

Melville, Charles, "Dokux Khatun," Encyclopadia Iranica, vol. 6. London: Routledge \& Kegan Paul, 1997.

Michel the Syrian, tr. J.B. Chabot. Chronique de Michel le Syrien, Patriarche jacobite d'Antioche, 4 vols. Paris, 1900-10.

Mustawfi, Hamdallah tr. G. Le Strange, Nu₹hat al-Qulub. Luzac \& Co., London, 1919. Persian text. London, 1915.

Stephannos Orbelian, tr. Marie Brosset. Histoire de la Sioune. St. Petersbourg, 1864.

Segal, J.B. "Syriac Chronicles as source material for the history of the Middle-East," in Lewis, Bernard \& Holt, P.M. eds., Historians of the Middle-East, London: Oxford Uiniversity Press.

Tarzi, Joseph, "Maphryono Mar Gregorious Youhanon Bar Ebroyo" [http://www.netadventure.com/ soc/Biogr/BarHeb/TarziBar. html]

Teule, H. "Bar Hebraeus' Syriac \& Arabic Secular Chronicles." in Ciggaar, Davids, Teule, eds. East \& West in the Crusader States. Leuven, 1996. 
Teule, H. "Ebn al-'Ebri," Encyclopadia Iranica, vol. 7. London: Routledge \& Kegan Paul, 1997.

Tusi, Nasir al-Din, ed. \& tr. by F. Nau, Le Livre de l'Ascension de l'Esprit sur la Forme du ciel et de la Terre, Bibl. De l'Ecole des Hautes Etudes, Sciences philoologiques et historiques 121, 2 vols. Paris, 18991900.

Vardan, tr. R.W. Thomson. "The Historical Compilation of Vardan Arewelc'i,"Dumbarton Oaks Papers, 43 pp. 125-226. Washington, 1989.

Vryonis, Speros, The Decline of Medieval Hellenism in Asia Minor. Berkeley \& Los Angeles: University of California Press, 1971.

Wright, William, A Short History of Syriac Literature. London: Adam \& Charles Black, 1894. 
